\title{
Abnormal expression of the human CD44 gene in early colorectal malignancy with special reference to variant exon $9(9 \mathrm{v})$
}

\author{
K Kawahara, T Yoshino, N Kawasaki, K Miyake, T Akagi
}

\begin{abstract}
Aims-To examine the expression of CD44 variant exon 9 in early colorectal malignancies.

Methods-Formalin fixed, paraffin wax embedded tissue sections from 30 cases of tubular adenoma and 35 cases of adenoma with focal carcinoma of the colon were examined immunohistochemically using a monoclonal antibody (MAb 11.24) directed against CD44-9v.

Results-In the normal colorectal mucosa immunoreactivity was confined to the basal part of the crypts and was expressed in less than $10 \%$ of crypt cells. CD44-9v was expressed in the superficial part of tubular adenoma with mild atypia in $67 \%$ of the cases and in $19 \%$ of the tumour cells. The immunoreactivity was observed along the basement membrane in mild atypia, as in the non-neoplastic crypts. In the course of progression to severe atypia the spatial polarity of immunoreactivity was lost, and the extent of CD44-9v expression increased in intensity and in the percentage of positive cases and positive cells. In the carcinomatous lesions of adenoma with focal carcinoma, $94 \%$ of the cases and $44 \%$ of the tumour cells were positive for CD44-9v protein.
\end{abstract}

Conclusion-CD44-9v may be overexpressed at the early stage of colorectal tumorigenesis and this increase continues thoughout the course of the disease. (F Clin Pathol 1996;49:478-481)

Keywords: colorectal carcinoma, adenoma with focal carcinoma, tumour marker, colorectal tumorigenesis, CD44 variant exon 9, immunohistochemistry.

CD44 is a ubiquitous transmembrane glycoprotein that has putative functions in cell-cell and cell-matrix adhesion, participating in lymphocyte homing, haemopoiesis, cell migration, and metastasis. ${ }^{1-4}$ In addition to the smallest standard CD44 isoform (CD44s), several larger variant isoforms are generated by alternative splicing of at least 10 exons inserted at the extracellular domain of the protein. ${ }^{5}$ In contrast to CD44s, limited data are available about the expression and function of CD44 variants (CD44v).

In normal human tissues most epithelia express variant exon 9 (exon $9 \mathrm{v}$ ), but much fewer express variant exons 4 or 6 . The highest expression of CD $44 \mathrm{v}$ is observed in the basal cells of stratified squamous epithelium and generative cells of glandular epithelium. Exon $6 \mathrm{v}$ is expressed only in squamous and glandular epithelia. ${ }^{6} 7 \mathrm{CD} 44-9 \mathrm{v}$ is very weakly expressed on leucocytes, and CD44-6v and $-4 \mathrm{v}$ are virtually absent. However, exons $9 \mathrm{v}$ and $6 \mathrm{v}$ are transiently upregulated on $\mathrm{T}$ cells after mitogenic stimulation. ${ }^{6}$ In rats, expression of exon $6 \mathrm{v}$ conferred metastatic potential to nonmetastasising pancreatic carcinoma cells. ${ }^{9}{ }^{10}$

Several CD44v isoforms are also overexpressed in human tumours, including colorectal carcinomas..$^{811-16}$ Regarding colorectal tumorigenesis, there are two theories which have been the subject of much discussion: the de novo carcinogenesis theory ${ }^{217} 18$ and the adenoma-carcinoma sequence theory. ${ }^{19-21}$ Recently, it has been reported that expression of CD44-6v, which is a human homologue of the rat metastasis associated variant of CD44, is largely restricted to the advanced stages of tumour development and is also found at a greater incidence and intensity in metastatic than in non-metastatic carcinomas. ${ }^{16}$ However, little is known about the expression of exon 9v in colonic adenomas and cancers. The present study was conducted to investigate the expression of CD44-9v on human colonic polyps with particular attention to early colonic carcinogenesis from the standpoint of the multistep carcinogenesis model. ${ }^{22}$

\section{Methods}

Sixty five colonic polyps were selected from the files of the Department of Pathology, Okayama University Medical School. All of them had been resected by endoscopic polypectomy, fixed in $10 \%$ buffered or non-buffered formalin, and embedded in paraffin wax. They comprised 35 cases of adenoma with focal carcinoma, 18 of adenoma with mild atypia, and 12 of adenoma with moderate atypia.

\section{IMMUNOHISTOCHEMISTRY}

A monoclonal antibody (MAb 11.24), which recognises an epitope in the exon $9 \mathrm{v}$ encoded region of $C^{4} 4 v^{6} 7$ and reacts well with formalin fixed, paraffin wax embedded tissue, was used for immunohistochemistry. This monoclonal antibody was produced by immunising mice with a bacterially synthesised fusion protein corresponding to exons $3 \mathrm{v}$ to $10 \mathrm{v}$. Specificity for the exon $9 \mathrm{v}$ product was determined by enzyme linked immunosorbent assay and a blocking test using a smaller fusion protein and a specific peptide, respectively. ${ }^{6}$ 

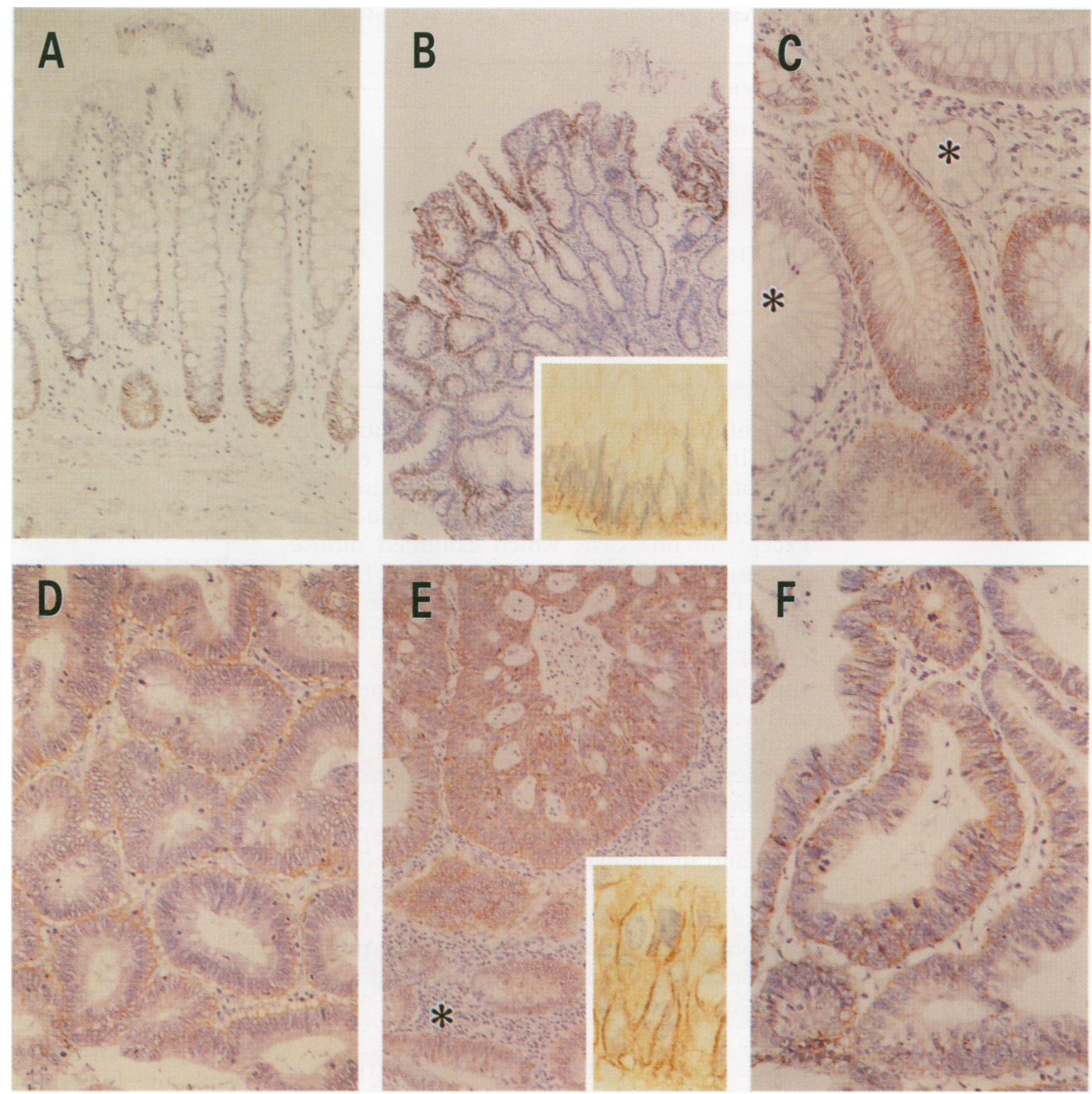

Figure 1 Immunostaining of CD44-9v. (A) Normal colonic mucosa. Only the cells in the lower fourth or fifth of the crypt are stained weakly. (Original magnification $\times 100$.) (B) and (C) Tubular adenoma with mild atypia. Immunoreactivity is mainly observed in the superficial part of the polyp and along the basement membrane. ${ }^{\star}$ Non-neoplastic crypts. (Original magnification $(B) \times 40$; inset $\times 200$; $(C) \times 170$.) (D) Tubular adenoma with moderate atypia. Immunoreactive cells are also observed in the deeper portion of the polyp. (Original magnification $\times 130$.) (E) Carcinomatous lesion of adenoma with focal carcinoma. Immunoreactivity loses polarity and is observed diffusely and more strongly in the tumour cells. ${ }^{\star}$ The adenomatous portion. (Original magnification $\times 90$; inset $\times 200$.) (F) Adenomatous glands with severe atypia adjacent to the carcinomatous lesion showing increased staining even in the cells near the luminal surface. (Original magnification $\times 170$.)

Serial sections ( $3 \mu \mathrm{m}$ thick) from paraffin wax embedded tissues were deparaffinised, heated at $98^{\circ} \mathrm{C}$ for 20 minutes in $500 \mathrm{ml}$ distilled water, and washed in phosphate buffered saline (PBS). After endogenous peroxidase was blocked by incubation in $100 \%$ methanol containing 3\% hydrogen peroxide for 30 minutes, the specimens were washed in PBS, incubated in $10 \%$ fetal calf serum for 30 minutes to block non-specific background staining, and then reacted with $\mathrm{MAb} 11.24$ (diluted 1 in 20) at $4^{\circ} \mathrm{C}$, overnight. After washing with PBS, the sections were reacted with peroxidase conjugated Streptavidin for 30 minutes. Diaminobenzidine was used as a chromogen. Normal mouse IgG (UPC, mouse IgG2a, Sigma, St Louis, Missouri, USA) was used as a class match negative control, and human epidermis was used as a positive control.

Cells were evaluated as positive when any immunoreactivity was seen on their surfaces, and 500 to 1000 cells in the randomly selected area showing similar histology were evaluated for each case. The positive rate (number of positive cells/total number of cells observed) was estimated by two investigators ( $\mathrm{KK}$ and TY) independently, and only those cases which were estimated similarly were analysed in this study. Less than $10 \%$ of the cells in the normal colorectal epithelium were positive, so cases with over $10 \%$ positive cells were regarded as positive. Statistical analyses were performed using Student's $t$ test.

\section{HISTOLOGICAL EVALUATION}

Specimens, $6 \mu \mathrm{m}$ thick, stained with haematoxylin and eosin were evaluated histologically. Atypia of colonic adenoma were diagnosed according to the histological criteria recommended by the Japanese Research Society for Cancer of the Colon and Rectum. ${ }^{23}$

\section{Results}

EXPRESSION OF CD44-9V IN NORMAL

COLORECTAL MUCOSA AND TUBULAR ADENOMAS CD44-9v was only weakly expressed on the cells in the lower fourth and fifth of the crypts, but not on the surface epithelium. Less than 
Table 1 Expression of CD44 variant exon 9 in colorectal tumours, given as the number (\%) in each group

\begin{tabular}{llllllll}
\hline \multicolumn{7}{l}{ Percentage of positive cells } & \\
\cline { 2 - 6 } Histological diagnosis & $0-9$ & $10-29$ & $30-49$ & $50-69$ & $70-100$ & Total \\
\hline $\begin{array}{l}\text { Tubular adenoma with } \\
\text { mild atypia }\end{array}$ & $6(33)$ & $5(28)$ & $7(39)$ & $0(0)$ & $0(0)$ & 18 \\
$\begin{array}{c}\text { Tubular adenoma with } \\
\text { moderate atypia }\end{array}$ & $2(17)$ & $2(17)$ & $6(50)$ & $1(8)$ & $1(8)$ & 12 \\
$\begin{array}{c}\text { Adenomatous lesion of } \\
\text { adenoma with focal } \\
\text { carcinoma }\end{array}$ & $6(18)$ & $15(44)$ & $9(26)$ & $4(12)$ & $0(0)$ & 34 \\
$\begin{array}{c}\text { Carcinomatous lesion of } \\
\text { adenoma with focal } \\
\text { carcinoma }\end{array}$ & $2(6)$ & $7(20)$ & $6(17)$ & $10(29)$ & $10(29)$ & 35 \\
\hline
\end{tabular}

$10 \%$ of the cells in the crypts were positive (fig 1A). Immunoreactivity of exon $9 \mathrm{v}$ in tubular adenoma with mild atypia was mainly restricted to the superficial part of the adenoma except for one case, which exhibited diffuse distribution of the positive cells (fig $1 \mathrm{~B}$ and 1C). Tubular adenomas with moderate atypia showed variable distribution of positive cells. CD44-9v positive cells were seen only in the superficial part of the tumour in some cases and were distributed diffusely from the surface to the deeper areas in others. Strong immunoreactivity was observed along the basement membrane (fig 1D). The percentage of positive cases in tubular adenomas with mild atypia was $67 \%$ and in tubular adenomas with moderate atypia was $83 \%$ (table 1 ). The average percentage of positive cells was $19 \%$ in tubular adenomas with mild atypia and $30 \%$ in tubular adenomas with moderate atypia; this difference was not statistically significant.

\section{EXPRESSION OF CD44-9V IN ADENOMA WITH} FOCAL CARCINOMA

Most carcinoma tissues were strongly positive for the exon $9 \mathrm{v}$ product. Carcinoma cell immunoreactivity was stronger than that of the surrounding adenoma cells and showed diffuse staining without polarity. The adenomatous lesion, which showed weak staining localised to the basal part of the crypt, could be clearly distinguished (fig 1E). Positive immunoreactivity was observed in $94 \%$ of carcinomatous lesions and in $82 \%$ of adenomatous lesions which contained focal carcinoma. An average of $44 \%$ of the carcinoma cells stained positively. The adenomatous lesions, when associated with focal carcinoma, usually showed moderate to severe atypia, and an average of $23 \%$ of these adenoma cells expressed CD44-9v. However, the adenomatous glands with severe atypia adjacent to the carcinoma exhibited increased staining even in the cells near the luminal surface (fig 1F). The percentage of positive cells in the carcinomatous lesion was significantly greater than that in the adenomatous lesions with focal carcinoma $(p<0.0001)$ and that in tubular adenoma with moderate atypia $(\mathrm{p}<0.02)$.

\section{Discussion}

Wielenga et $a l^{16}$ have already reported expression of CD44 variant proteins in colorectal carcinomas and adenomatous polyps using frozen sections. In normal colonic epithelium epitopes encoded by exons $7 v$ and $8-10 v$ were weakly expressed and localised to the base of the crypt, similar to expression of CD44s proteins. The other variant CD44 exons $(3 v-6 v)$ were not expressed. Overexpression of exons $5 \mathrm{v}$ and $7-10 \mathrm{v}$ was observed ubiquitously in early and large colorectal adenomas and early and advanced carcinomas. Expression of variants containing exon $6 \mathrm{v}$ sequences was largely restricted to the advanced tumour stages and was more intense in metastatic than in non-metastatic carcinomas. However, a detailed histology is difficult to determine using frozen sections only, and Wielenga et al did not use a monoclonal antibody specific to exon 9v protein alone. ${ }^{16}$

In the present study, we analysed formalin fixed, paraffin wax embedded tissue sections from colorectal polyps resected by endoscopic polypectomy. In the preliminary experiment we tested three monoclonal antibodies recognising epitopes in the exon $4 \mathrm{v}$ (MAb 11.10), 6v $(\mathrm{MAb} 11.31)$ and $9 \mathrm{v}$ encoded regions (MAb 11.24) of CD $44 v^{7}$ Of these, only MAb 11.24, recognising the exon $9 \mathrm{v}$ product, stained paraffin wax sections, after pretreatment in a microwave oven. Using this monoclonal antibody, staining achieved in paraffin wax sections of human stratified squamous epithelium and colonic mucosa was comparable with that in frozen sections.

In colorectal tubular adenomas CD44-9v was expressed more strongly in mild than moderate atypia, though not significantly. The expression pattern in adenomas was similar to that in normal colorectal epithelium, showing the regular distribution along the basement membrane. In crypts with severe atypia expression of CD44-9v was no longer polar, and the intensity of staining and the percentage of positive cells increased. Furthermore, analysis of five cases of advanced colorectal cancer revealed intense expression of exon $9 \mathrm{v}$ in an average of $66 \%$ of cancer cells (data not shown).

Expression of exon 9v was also observed in $67 \%$ of cases of tubular adenoma with mild atypia. These data suggest that this variant protein may be overexpressed at the very early stages of colorectal cancer, as observed for the CD44s and exon $7 \mathrm{v}, 8-10 \mathrm{v}$ proteins ${ }^{13}{ }^{16}$ and becomes more widespread at the more advanced stages, as seen for exon $6 \mathrm{v}$ protein. ${ }^{16}$ Two of the cases of adenoma with focal carcinoma did not express CD44-9v in the adenomatous and carcinomatous lesions, although the surrounding normal crypt bases stained positively. This suggests that adenomas may progress to cancer without expressing exon 9v. Further studies are required for confirmation of this point.

In summary, CD44-9v may be overexpressed at the early stages of colorectal tumorigenesis and the level of expression increases throughout the course of the disease.

The authors thank Ms M Inoko and Mr R Domatsu for excellent technical assistance, and Dr S Nakamura for helpful advice in the preparation of the manuscript. The authors also express their thanks to $\mathrm{Dr} U$ Günthert, The Basel Institute for Immunology, Switzerland, for kindly providing the 11.24 monoclonal antibody. 
1 Haynes BF, Liao H-X, Patton KL. The transmembrane hyaluronate receptor (CD44): multiple functions, multiple forms. Cancer Cells 1991;3:347-50.

2 Haynes BF, Telen MJ, Hale LP, Denning SM. CD44: a molecule involved in leukocyte adherence and T-cell activation. Immunol Today 1989;10:423-8.

3 Lesley J, Hyman R, Kincade PW. CD44 and its interaction with the extracellular matrix. Adv Immunol 1993;54:271-335.

with the extracellular matrix. Adv Immunol 1993;54:271-335. 1992;103:293-8.

5 Screaton GRM, Bell MV, Jackson DG, Cornelis FB, Gerth U, Bell JI. Genomic structure of DNA encoding the lymphocyte homing receptor CD44 reveals at least 12 alternatively spliced exons. Proc Natl Acad Sci USA 1992; 89: $12160-4$.

6 Mackay CR, Terpe HJ, Stauder R, Marston WL, Stark H, Günthert U. Expression and modulation of CD44 variant isoforms in humans. $\mathcal{F}$ Cell Biol 1994;124:71-82.

7 Terpe HJ, Stark H, Prehm P, Günthert U. CD44 variant isoforms are preferentially expressed in basal epithelia of non-malignant human fetal and adult tissues. Histochemistry 1994;101:79-89.

8 Koopman G, Heider KH, Horst E, Adolf GR, van den Berg F, Ponta H, et al. Activated human lymphocytes and aggressive non-Hodgkin's lymphoma express a homologue of the rat metastasis-associated variant of CD44. F Exp Med 1993;177:897-904

9 Günthert U, Hofmann M, Rudy W, Reber S, Zoller M, Haussmann I, et al. A new variant of glycoprotein CD44 confers metastatic potential to rat carcinoma cells. Cell 1991;65:13-24.

10 Rudy W, Hofmann M, Schwartz-Albiez R, Zoller M, Heider $\mathrm{KH}$, Ponta $\mathrm{H}$, et al. The two major CD44 proteins expressed on a metastatic rat tumor cell line are derived expressed on a metastatic rat tumor cell line are derived
from different splice variants: Each one individually from different splice variants: Each one individually
suffices to confer metastatic behavior. Cancer Res 1993; suffices to

11 Heider KH, Dämmrich J, Skroch-Angel P, Müller-
Hermelink HK, Vollmers HP, Herrlich P, et al. Differential expression of CD44 splice variants in intestinal- and diffuse-type human gastric carcinomas and normal gastric mucosa. Cancer Res 1993;53:4197-203.

12 Heider KH, Hofmann M, Hors E, van den Berg F, Ponta $\mathrm{H}$, Herrlich $\mathrm{P}$, et al. A human homologue of the rat metastasis-associated variant of $\mathrm{CD} 44$ is expressed in colo-

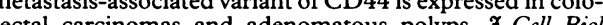
1993;120:227-33 and adenomatous polyps. F Cell Biol

13 Matsumura Y, Tariu D. Significance of CD44 gene products for cancer diagnosis and disease evaluation. Lancet 1992;340:1053-8.

14 Mayer B, Jauch KW, Günthert U, Figdor CG, Schildberg FW, Funke I, et al. De-novo expression of CD44 and survival in gastric cancer. Lancet 1993;342:1019-22.

15 Tanabe K, Ellis LM, Saya H. Expression of CD44R1 adhesion molecule in colon carcinoma and metastasis. Lancet 1993;341:725-6.

16 Wielenger VJM, Heider $\mathrm{KH}$, Offerhaus JA, Adolf GR, Van den Berg FM, Ponta H, et al. Expression of CD44 variant proteins in human colorectal cancer is related to tumor proteins in human colorectal cancer is re

17 Byron EC, Stromeyer FW. Small nonpolypoid carcinomas of the large intestine. Cancer 1983;51:1760-3.

18 Harlan JS, Norman BF, Michael FA. The small carcinoma of the large bowel. Am F Surg Pathol 1979;13:39-46.

19 Fenoglio CM, Pascal RR. Colorectal adenomas and cancer. Cancer 1982;50:2601-8.

20 Morson BC, Dawson IMP. Gastrointestinal pathology. 3rd edn. Oxford: Blackwell Scientific Publications, 1990.

21 Muto T, Bussey HJR, Morson BC. The evolution of cancer of the colon and rectum. Cancer 1975;36:2251-70.

22 Fearon ER, Vogelstein B. A genetic model for colorectal tumorigenesis. Cell 1990;61:759-67.

23 Japanese research society for cancer of the colon and rectum. General rules for clinical and pathological studies on cancer of the colon, rectum and anus. Tokyo: Kanehara, 1994. 